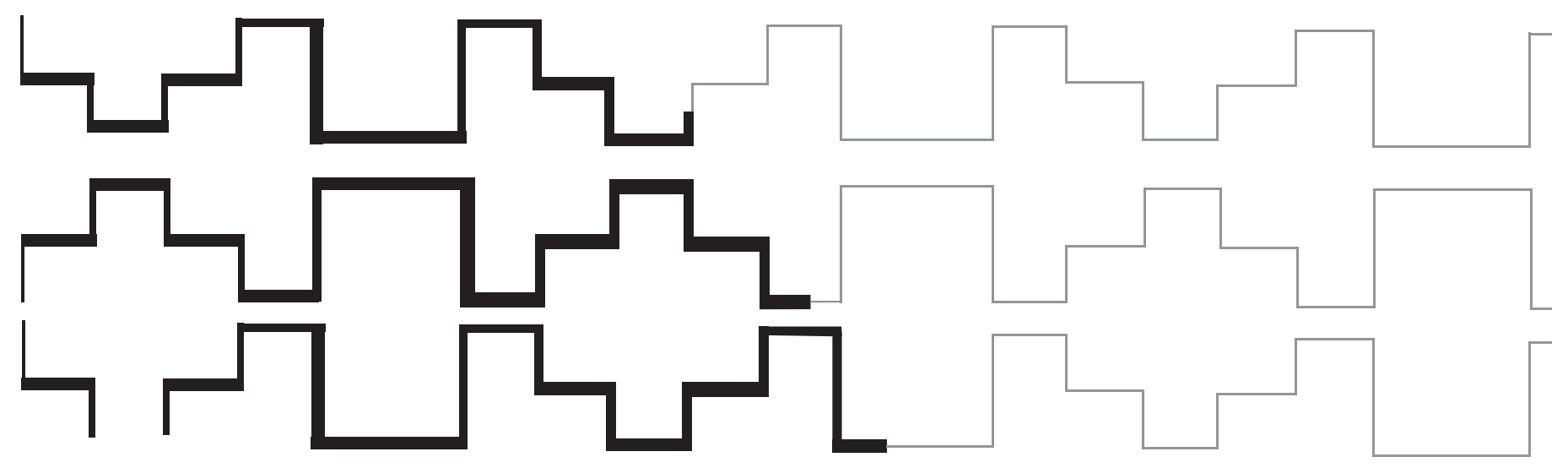

\title{
Gaivotas voando livres aos ventos visíveis
}

\author{
Gregory Magalhães Costa
}

\section{Resumo}

$\mathrm{O}$ artigo consiste na interpretação da tensão entre autonomia e libertação contra a opressão e a tirania, refletida na filosofia, na sociedade e no texto poético, enfocando a literatura brasileira, em especial a obra espiral de Guimarães Rosa, sobretudo no que tange o Grande Sertão: veredas, e sob a luz das ideias de Hannah Arendt. A abordagem abrangerá a espacialidade e temporalidade da cidade (Rio de Janeiro), comparada à literária, em suas formas de ocupação, imposição e apropriação.

Palavras-chave: Existenz; libertação; tirania; literatura; sociedade; dignidade.

\begin{abstract}
The article is the interpretation of the tension between autonomy and freedom from oppression and tyranny, reflected in philosophy, society and in the poetic text, focusing on Brazilian literature, in particular the "spiral" work of Guimarães Rosa, especially concerning The Devil to Pay in the Backlands, and highlighted by the ideas of Hannah Arendt. The approach will cover the spatiality and temporality of the city (Rio de Janeiro), compared to the literature, in its forms of occupation, imposition and appropriation.
\end{abstract}

Keyword: Existenz; tyranny; freedom; literature; society; dignity. 
outraTravessia

E a coisa viera vindo, do estilo dragocrático-mandológico-coactivo ao cabalístico-estatístico, daí para o messiânico-palimpsésticoparafrástico, depois para o cozinhativo-compadresco-recordante, e assim, de caçarola a tigela, de funil a gargalo, o fino fluído inicial se fizera caldo gordo, mui substancial e eficaz; tudo isto entre parênteses, para mostrar uma das razões por que a política é ar fácil de se respirar - mas para os de casa, que os de fora nele abafam, e desistem. (ROSA, 2001, p. 140)

Em meados do século XVIII, Rousseau situou a origem da miséria e da desigualdade entre os homens na propriedade privada (ROUSSEAU, 1980). Do primeiro para o segundo decênio do século seguinte, Proudhon escreveu seu texto clássico contra essa mesma propriedade privada e, provavelmente, foi o primeiro a se declarar anarquista, utilizando o termo para descrever assuntos ideológicos. Para ele arché significa autoridade, para Arendt tanto começo quanto regra, já Ronaldes de Melo e Souza define como princípio. De qualquer forma, considerando as três definições, a anarquia será a negação da autoridade ou de um começo preestabelecido, de uma regra predeterminada ou um principio imposto a priori. Na verdade, até o ano de 1871, não havia uma distinção clara entre comunistas e anarquistas e todos eram considerados comunistas. Com a Comuna de Paris em 1871, os debates sobre a necessidade ou não de uma ditadura do proletariado para que se atinja a sociedade sem classes se intensificaram mais do que já eram, tornando a relação política entre Marx e Bakunin insuportáveis, desembocando na expulsão deste último da Associação Internacional dos Trabalhadores no congresso de Haia em 1872. Pois foi justamente esta cisão no seio da Internacional que gerou a distinção entre comunistas autoritários ou marxistas, por acreditarem na ditadura do proletariado, e comunistas libertários, que acreditavam ser possível alcançar a sociedade sem classes por meio da ação livre, em solidariedade e pé de igualdade com o outro. O próprio Marx escreveu um texto a favor da Comuna de Paris, "A guerra civil na França", (MARX, 2008, p. 339-432) defendendo inclusive que a comuna (portanto não a ditadura do proletariado) seria o caminho para a sociedade sem classes. É interessante observar que foi a recusa por parte dos anarquistas de aceitar a premissa maquiavélica de que os fins (sociedade sem classes) justificam os meios (ditadura do proletário) que os levou a tal rompimento. Para o pensamento libertário, a liberdade só se alcança pela liberdade. Nessa perspectiva, a ditadura do proletário não geraria a sociedade sem classes, mas uma nova luta de classes entre os governantes (proletários) e a recém surgida classe governada. Há também algumas teorias anarquistas que encontram a justificativa da violência como defesa (resposta) contra uma violência anterior, o chamado anarquismo sindical, de Malatesta. Mas o que realmente define o sistema libertário é sua teoria econômica elaborada por Proudhon e denominada "mutualismo", que consiste basicamente no fim da diferença entre trabalho intelectual e trabalho braçal. José Pacheco recentemente assim definiu o mutualismo: "a simbiose, uma relação permanente e duradoura com benefícios para todos os participantes na associação; a cooperação mantém a reciprocidade de vantagens". (PACHECO, 2008, p. 84) Todos são responsáveis pela produção social tanto braçal quanto intelectual. Esse sistema político se notabiliza pela ação direta livre dos cidadãos autônomos que se organizam em associações livres segundo suas necessidades e anseios; prática que constitui uma verdadeira democracia participativa. Foi Karl Löwith quem percebeu que Proudhon coloca nas mãos dos homens e da justiça 
humana o rumo de todos os assuntos humanos; o homem substitui Deus, uma vez que a crença no progresso humano tem que suplantar a fé na providência (LÖWITH, 1977, p. 69). Essa crença instaura uma teoria econômica microcósmica já que a ação livre se dá entre indivíduos contextualizados em cooperativas, que se relacionam solidariamente; já o comunismo ao crer numa ditadura do proletário, num governo único para todos, promove uma atuação econômica macrocósmica. A teoria econômica libertária atualmente é conhecida sob o nome de autogestão.

Somos seres inacabados, portanto, em eterna construção, em devir. A realidade, como nós, é inacabada e está em permanente mudança. Se mudamos permanentemente é possível mudarmos para melhor, eis o princípio. Também para Eduardo Portela a "realidade... é... um dinamismo, contínuo fazer-se, permanente vir-a-ser" (PORTELA, 1983, pg. 199). Já Walnice Galvão vai mais longe: "Deixar-se levar pelo movimento e aceitar a mudança é a maneira de viver com plenitude. Querer subjugar o mundo e fazêlo curvar-se às suas ordens pode redundar em danação" (GALVÃO, 1986, p. 130). Não é uma total verdade que a anarquia não aceite regras. Na verdade ela não aceita regras preestabelecidas pelo simples fato de que uma regra geral nunca prevê as particularidades dos eventos, portanto é necessário que cada evento seja julgado e compreendido por regras que deem conta de suas demandas. Essas regras têm que ser formuladas polifonicamente de acordo com as necessidades e demandas particulares de cada evento particular e seus participantes. Pode-se dizer até que há uma lei universal que rege o pensamento libertário, a cristã: O que você não quer que seja feito para você, não faça para os outros. Mesmo Hannah Arendt situa a liberdade como o direito assegurado a todos de tratar dos assuntos que um dia foram de César. Ela ainda observa que o conceito de liberdade não tem origem religiosa, não podendo ser confundida com o livre arbítrio, que é a liberdade de escolher entre coisas dadas de antemão. Para Arendt é desde Kant que se sabe que o eu não é objeto do pensamento. Na verdade, o homem teria voltado a ser o tema, deixando de ser biológico, histórico e socialmente determinado desde Husserl, para quem o mundo deixa de ser algo dado e passa a ser algo criado pelo homem. Assim ele busca tornar o mundo novamente humano. Porém, desse modo, ele tentou tornar o homem aquilo que ele não é e não pode ser: criador do mundo e de si mesmo. Justamente a relação ser, homem e existência é a temática fundamental da filosofia da "Existenz".

Segundo Arendt, o termo "Existenz" apareceu pela primeira vez em seu sentido moderno no Schelling tardio. Ele começa a filosofia moderna, pois explica que está ocupado com o indivíduo que "deseja ter um Deus providencial" que é o "senhor do ser". Assim, o indivíduo se liberta do universal uma vez que não é o universal no homem que busca a felicidade, mas o indivíduo. Para ele, a "Existenz" seria um puro "Isto". Com o reconhecimento de que o "Quê" não pode explicar o isso, a filosofia moderna começa por uma colisão com a pura realidade. Filosofamos sobre as situações-limites tais quais morte, destino e acaso porque a realidade é algo que não pode ser evitada. "Viver é perigoso", diz um dos leitmotiv de Riobaldo. O narrador-personagem vive sempre momentos-limite, como quando toma um tiro caindo do barranco e vai re-acordando com a lembrança de Diadorim dando de cara com ela; como em suas batalhas e decisivos jogos de amor. Esse amor é decidido num "jogo de pedra", remetendo ao acaso que permeia todo amor e toda a vida. Kant fundou a nova filosofia por destruir a unidade entre ser e pensamento, que pressupunha a coincidência entre essência e existência. Para Arendt o 
"cogito" cartesiano é inútil, justificando, com Nietzsche, que essa resposta nunca prova o ego cogitans, mas apenas o cogitare.

Parece-nos óbvio, na verdade lógico, que uma época predominantemente esclarecida gera fortuna e boas condições de vida para a humanidade, conforto, porém para Giambattista Vico o movimento da história é bem outro. Primeiramente vem a idade dos Deuses "em que os homens da gentilidade acreditavam viver sob governos divinos, julgando que tudo lhes fosse determinado através dos auspícios e dos oráculos, ambos representando os mais velhos eventos da história profana"; depois a idade dos Heróis "na qual, entre todos eles, tiveram domínio as repúblicas aristocráticas, já que se apoiavam numa qualificação por eles considerada de natureza superior à dos plebeus"; e enfim a idade dos Homens "em que todos se reconheceram iguais pela natureza humana, razão por que, primeiramente, celebraram as repúblicas populares e, finalmente, as monarquias, ambas formas de governos humanos." (LÖWITH, 1977, p. 133). Essa é a definição clássica das épocas viquianas, que Löwith chamou de temporalidade cíclica uma vez que ao chegar na última época há um recurso à primeira época renovada, que se repete originária. Marco Lucchesi apontou que "Collingwood assinalou que o sistema viquiano é espiral e não um círculo." (LUCCHESI, 1999, p. 21). Também Antonio Moreira Barbosa de Melo observa que em Vico "a ordenação temporal processa-se em espiral" (BARBOSA, 2005, p. XIX). Vico descreve sua última época, a da linguagem jurídica, racional como a época da barbárie e da decadência das sociedades. O primado da razão enlouquece os homens constituindo-se a época de um Nero, de um Calígula, ou a de um Hitler. Parece-me bem evidente que todos os regimes totalitários são altamente sistematizados logicamente, de modo a não se importar em gerar o sofrimento humano para alcançar seus objetivos de dominação. Mas abandonando o corpo abandona-se também todo o ser. A própria Arendt define a lógica rigorosa como a característica fundamental do pensamento totalitário.

Pode ser que tudo isso pareça só um cenário típico de um pós-segunda-guerra, mas hoje em dia, mesmo, vivemos uma era altamente tecnológica, do mais alto esclarecimento e tudo isso gerou nada mais do que o aquecimento global, o derretimento das geleiras, os tsunamis, "los niños", "las niñas" e muitos outros nomes para furacões e terremotos, que aumentam de frequência e poder de destruição a cada aparição. A fome e a miséria ainda primam no primado da razão. Estamos chegando ao fim de uma era, da culminância da lógica que gerou o declínio na barbárie. O nosso Rio de Janeiro é um belo exemplo pós-moderno da barbárie gerada pelo excesso de lógica, que, como vimos, por definição é o fascismo. Assim, Iná Elias de Castro designa a função das instituições políticas como a de aumentar o grau de previsibilidade (CASTRO, s/d, p. 147) e para Leda Velloso Buonfiglio, mesmo em gestões mais democráticas "o Estado... não abre mão de sua função de regulador dos espaços,... produzindo o espaço da dominação." (BUONFIGLIO, 2007, pg. 275). O Rio de Janeiro criou os caveirões e tem montanhas de recursos para gastar com tropas de elites, seus centros de treinamentos e seus treinamentos propriamente ditos, operações onerosas, pesquisas encomendadas, espionagem, burocracias e corrupção. Sobra dinheiro para armas e balas que acuam o professor estadual na parede, com seu salário de 700 Reais e sua falta de preparo e de dignidade. E dinheiro para dar salários dignos, plano de carreira, dedicação exclusiva e condições de trabalhos para os docentes? Daí não. A verba já foi toda gasta com operações para subir morros atirando nos moradores pobres, pretos, pardos e nordestinos. 
Afinal, segurança é oprimir, torturar e matar essas minorias, se é que elas são minorias. Atualmente, segurança é isso, não se pensa que investimentos em educação, dignidade e solidariedade possam melhorar o nosso quadro de segurança. O papel do educador e do pensador está subjugado aos meios de técnicas produtivistas. Afinal, pensar desacelera a produção! É evidente que é a lógica que diz que se o foco é a segurança pública então o dinheiro deve ser gasto em armas letais e truculência. Se a lógica diz isso, a compreensão provavelmente diria outra coisa. Nesse sentido vejo Hannah dizendo: "invistam seu dinheiro em instrumentos que gerem a dignidade da liberdade, ações livres e solidárias". Não é isso que é feito e esses cães ferozes são programados para reagir e matar sempre que se sintam ameaçados ou no direito de fazer isso, como aconteceu há pouco tempo aqui na Tijuca em que os policiais acharam que tinha algum bandido num carro de família e meteram bala, matando o filho de um casal de classe média. Ora, Édipo nos ensina: queremos sempre alienar o mal social, mas quando paramos para investigá-lo com rigor, percebemos que o único culpado pelos males sociais somos nós mesmos. Pois bem, se a elite e a classe-média cariocas e fluminenses topam legitimar e financiar essas desastrosas políticas truculentas como poderão reclamar se o cão raivoso, que eles criaram para matar os filhos dos outros, agora mataram seu filho? Ora, esse não será apenas o outro lado da moeda de um policial que todo dia mata pobre, preto, pardo e nordestino? Não há como isolar a violência em uma só classe. Sempre a violência cometida contra uma classe acaba resvalando na própria classe promotora dessa violência, ainda mais em uma cidade com a constituição urbanístico-social como a do Rio de Janeiro. No Rio morro e asfalto andam juntos; todas as áreas nobres, Zona Sul, Zona Oeste e alguns bairros da Zona Norte têm suas favelas, assim como o Centro, local da primeira favela, criada pelos combatentes de Canudos. Em outras cidades do país, como São Paulo e Porto Alegre, as classes subalternas ficam nas periferias. $\mathrm{O}$ grande problema do Rio não é ter uma quantidade maior de violência, como propaga a mídia. Seu problema é que sua violência dificilmente distingue classes. Mas isso, na verdade, é um problema para as elites, pois as classes desfavorecidas sofrem violências quase que diariamente. É só reparar que as torturas ocorridas em casas de recolhimento e prisões, sofridas por pobres, não geram celeuma na sociedade. Só há um jeito de não legitimar nem financiar a criação de policiais preparados para matar e para a truculência: não permitindo que eles sejam criados, não financiar esse tipo de política.

Ora, há dinheiro para construir muros em favelas que, de forma cínica, os governantes chamam de barreiras ecológicas e não há grana para construir moradias populares. Com isso ainda tentam jogar mais uma culpa nas costas das comunidades menos favorecidas, a culpa pelo desmatamento. É verdade que em pequena escala os oprimidos desmatam. Mas os oprimidos não dispõem das altas técnicas de desmatamento da elite que queima nações de florestas para plantar arroz e soja transgênica no pantanal e na Amazônia. Todos sabem que esses muros não trarão dignidade para essas comunidades, ao contrário; o que traria dignidade seria ter uma moradia digna e trabalho honesto e bem remunerado. Marcelo Lopes de Souza e Glauco Bruce Rodrigues percebem que os principais problemas das cidades são: a especulação imobiliária, o abandono de prédios e terrenos públicos e a falta de políticas habitacionais consistentes. Eles denunciam que "sobram imóveis desocupados e subutilizados, mas faltam moradias." (RODRIGUES; SOUZA, 2004, p. 97). Afirmação ratificada por Leda Velloso Buonfiglio (BUNFIGLIO, 2007, pg. 278). Nathalia Cristina Oliveira observa que 
o déficit habitacional é o principal intensificador dos movimentos sociais urbanos (os sem-teto), obrigando-os à sua multiplicação (OLIVEIRA, 2002, p. 1). Também para Leda Buonfiglio a origem dos movimentos sociais urbanos são os problemas cotidianos das classes pobres (BUNFIGLIO, 2007, p. 276). Nossa elite é uma das mais incultas entre todas, ela provém dos grandes latifundiários que estavam mais preocupados em produzir ora açúcar, ora leite e café, e a explorar a escravidão. Nossa classe média geralmente é entreguista e de pensamento colonial, se contenta em papagaiar teorias importadas, preconcebidas e desconexas ou então que ouviram na televisão. A nossa classe média é tão ingênua, ou se faz de ingênua, que uma mera mudança de nomes, de fascismo para choque de ordem, já justifica qualquer tirania. Este choque de ordem municipal, que é totalitário, nada mais faz do que perturbar os moradores de rua, prendendoos em abrigos insalubres geralmente sob regime de tortura, além da expropriação das mercadorias e espancamento dos camelôs. Muitas vezes os moradores de rua têm casa, mas, por ser longe, na periferia, não tendo dinheiro para o transporte e por trabalhar desde de manhã cedo, preferem dormir na rua. Outros foram despejados de favelas, tiveram a casa removida ou destruída por deslizamentos. Mas Buonfiglio observa que "No universo do desempregado ou do subempregado, o teto na cidade é ainda uma garantia em sua pobreza, antes da miséria completa." (BUONFIGLIO, 2007, p. 277). Ah, a prefeitura também reboca carros da classe média para arrecadar um troco e maquiar a ordem fascista do choque. Isso mesmo! O hoque de ordem nada mais é do que a ordem fascista do choque!

Eduardo Tomazine Teixeira e Matheus da Silveira Grandi detectam que, cartesianamente, espaço público significa convivência simultânea entre a igualdade (direitos e deveres iguais) e a diversidade (de comportamento, convicções políticas, religiosas etc.), mas Iná Elias de Castro percebe que são nos espaços públicos que ocorrem as tensões sociais, sendo políticos por excelência. Assim, esses espaços são arenas privilegiadas para o confronto entre os instituintes e as regras vigentes (CASTRO, 2004, p. 149). Portanto, o espaço dos livres diferentes pode se tornar o local da exclusão e da tirania, (CASTRO, 2004, pg. 141) uma vez que qualquer modelo que privilegie mais um do que outro poderá favorecer o exercício da tirania (Castro, 2004, p. 146). A relação assimétrica entre os membros de uma comunidade mediados pela propriedade privada gera os espaços apropriados, que, segundo Buonfiglio, são "construções coletivas, mediadas por relações sociais diretas." (BUONFIGLIO, 2007, p. 279). E as ocupações (semteto) são "uma forma de apropriação na cidade", uma vez que "ocupar envolve o ato de produzir o lugar." (BUONFIGLIO, 2007, p. 279). São Marcelo Souza e Glauco Rodrigues quem percebem que as ocupações são planejadas e organizadas pelos militantes do movimento, não são ações espontâneas e desordenadas. Mas, num país capitalista, o direito de propriedade prevalece sobre o de uma vida digna. Desse modo, as ocupações sofrem represálias por parte do Estado e dos proprietários dos imóveis (RODRIGUES; SOUZA, 2004, p. 99-100). Buonfiglio observa que "os novos movimentos de moradia... Com estratégias inéditas de ação coletiva revelaram uma prática sócio-espacial que influenciou diversos grupos nas inúmeras capitais do país: as ocupações" (BUONFIGLIO, 2007 , p. 277). Mas que estratégias são estas? Souza e Rodrigues levantam que as funções tanto do M.T.S.T. quanto do M.S.T. vão desde a luta contra o capitalismo, o latifúndio e a segregação residencial, até estratégias de ação, organização e mobilização de pessoas. A principal estratégia de ambos os movimentos, um no campo, outro na cidade, é a 
ocupação de prédios e terrenos vazios ou subutilizados. Suas práticas políticas, pedagógicas e de socialização se desenvolvem contribuindo para que as pessoas envolvidas tenham mais consciência de seus direitos enquanto cidadãs e ajudem na formulação de ações práticas (RODRIGUES; SOUZA, 2004, p. 99). Buonfiglio observa que os sem-teto atuam nos centro antigos da metrópole, onde há estoque imobiliário em abandono, que clama por função social (BUOFIGLIO, 2007, p. 267). Assim, Teixeira e Grandi falam da "instituição de uma democracia direta com um horizonte de superação radical da divisão estrutural entre dirigentes e dirigidos." (GRANDI; TEIXEIRA, $s / d$, p. 3). Eles observam que as ocupações são divididas em espaços privados, apartamentos; os coletivos, espaços de reunião, assembleias, festas, etc.; e os de uso comum, os corredores e banheiros. Aparentemente o espaço de maior politização seriam os de uso coletivo. Mas Teixeira e Grandi notam que os de uso comum são os mais decisivos politicamente (GRANDI; TEIXEIRA, s/d, p. 5). Ao falar do agir comunicativo, eles detectam que "com essa teoria Habermas pretende superar as formulações funcionalistas para as quais a ação dos sujeitos estaria voltada para o alcance de seus próprios fins e subordinadas... a "cálculos de ganho egocêntricos." Em contraponto eles propõem uma "situação em que os atores tratam de harmonizar internamente os seus planos de ação e só perseguir suas respectivas metas sob a condição de um acordo existente ou a se negociar sobre a situação e as consequências esperadas." (GRANDI; TEIXEIRA, s/d, p. 2). Já Souza e Rodrigues enfocam que "É necessário pensar e agir em muitas escalas, simultaneamente" (RODRIGUES; SOUZA, 2004, p. 120). Talvez por isso Iná de Castro defina a política como a "vontade instituinte do espaço concreto das relações sociais entre os diferentes", (CASTRO, 2004, pg. 143) e o direito como tanto o "direito de ser igual como a liberdade de ser diferente" (CASTRO, 2004, p. 146). Para ela os sujeitos sociais são "verdadeiros atores políticos" (CASTRO, 2004, p. 150). Na poética de Rosa a participação ativa do leitor como ator da narrativa é amplamente detectada por sua crítica, como por Paulo Rónai (RÓNAI, 2005, p. 30), Edna Nascimento e Lenira Covizzi, (COVIZZI; Nascimento, 1985, p. 33) Teresinha Ward, (WARD, 1984, p. 122) Leonardo Arroyo, (ARROYO, 1984, p. 104) Suzana Kampff Lages (LAGES, 1998, pg. 80) e Dau Bastos (BASTOS, 2007, pg. 76). Já Suzi Frankl Sperber sugere que o eixo estruturador da ação de "Grande Sertão: Veredas" é a busca da liberdade (SPERBER, 2002, p. 340). De qualquer forma, Buonfiglio define a cidade como "Objeto de luta" e a luta como "elemento constituinte da sociedade" (BUONFIGLIO, 2007, p. 266). Também é a luta pelo Sertão que constitui a sociedade sertaneja rosiana. Daí deriva o "direito à cidade" que para Buonfiglio transcende à moradia, mas não existe sem ela, que é seu elemento mais básico. Ele possui dois paradigmas: 1- o modo pelo qual o Estado internaliza o discurso do direito à cidade; e 2- o modo como os sem-teto encaram esse paradigma, na luta; (BUONFIGLIO, 2007, p. 267) e três princípios: 1- o exercício pleno da cidadania; 2 - a gestão democrática da cidade; e 3- a função social da propriedade privada (esta já instituída legalmente pelo estatuto das Cidades) (BUONFIGLIO, 2007, p. 270). Porém ela nota que o direito à cidade esbarra na propriedade privada, pilar da sociedade capitalista (Buofiglio, 2007, p. 268). Por fim, além dos perfis já apontados acima, quem são os sem-teto, quais perfis sociais o constituem? Para Buonfiglio "Os sem-teto são grupos organizados e constituídos como movimento social. O perfil é composto em sua maioria por famílias, mas também jovens casais endividados por aluguel..., em situação precária, vindos de cortiços ou nas inúmeras periferias... até mesmo moradores em área de risco." (BUONFIGLIO, 2007, p. 278). 
Vivemos o fim de uma era. É o homem cósmico, integrado de corpo e alma com os animais, os rios, mares, plantas, as gentes e consigo mesmo, que Guimarães Rosa tece em sua poética sertaneja. Tratando do Grande Sertão, é Consuelo Albergaria quem fala da correspondência do aprendizado dos pequenos aos grandes mistérios com o "homem integral" (ALBERGARIA, 1977, p. 140). Nelly Novaes Coelho e Ivana Versiani, analisando o herói rosiano, interpretam que ele é um "homem organicamente integrado no universo" (COELHO; VERSIANI, 1975, p. 1). Também para Dante Moreira Leite, em Rosa natureza e homem são isomórficos numa "interpenetração de homem e ambiente" (LEITE, 1979, p. 90). Incrivelmente, ou caminharemos na direção de Pedro Orósio e escutaremos o recado do morro ou podemos viver um paradoxo cada vez mais profundo entre homem e natureza. Por incrível que pareça há estreitas simetrias entre o sertanejo rosiano e o atual homem da periferia. É claro que seria raso considerar que existe unidade entre os moradores de comunidades pobres, favelas. Seria igualmente ingênuo considerá-los "homens integrais", mas tampouco podemos ignorar as congruências existentes entre eles e os sertanejos de Rosa. O chamado êxodo rural teve seu auge no Brasil, nas décadas de 50 e 60 , com o processo de modernização e industrialização de nosso país. O eixo civilizatório de nossa história se converte na linha narrativa guiada por Zé Bebelo na estória jagunça. A narração da estória, que se passa na república velha, acontece justamente na década de 50, provavelmente 1952. Muitos sertanejos abandonaram a terra, indo para as zonas litorâneas e centrais do país sob a promessa de melhoria de vida. Aquilo que a graúna do Henfil ironicamente chamava de "sul maravilha". Essas populações acabaram, na sua enorme maioria, subempregadas nas grandes cidades, formando muitas favelas, que hoje já predominam num centro urbano como o Rio, por causa dos fatores já apontados. Muito dessa integração deles com a natureza permanece, embora, como afirma Alaor Barbosa, a televisão esteja acabando com a língua do Sertão (BARBOSA, 1981, pg. 20). Já Alan Viggiano vai mais longe. Para ele, a televisão, a luz elétrica, esgoto, calças jeans, o rock no lugar das modas de viola, entre outros, estão acabando com o Sertão (VIGGIANO, 1993, pg. 57). De qualquer forma, para se chegar ao homem integral é preciso ainda dar o passo da autonomia, tornando-se sujeito de suas ações, processo que se tenta conquistar com as ocupações. Vale lembrar que uma das coisas que o Sertão rosiano é, é o interior, não só geográfico como também anímico. Cada sertanejo carrega consigo o seu Sertão. Enquanto o jagunço rosiano luta contra a imposição da civilização no Sertão, os sem-teto lutam contra a imposição da propriedade privada e do capitalismo. Enquanto as elites os marginalizam, os sem-teto se universalizam, integrando-se à sociedade e gerando um projeto de coletividade com relações simétricas. Os sem-teto são os legítimos descendentes dos jagunços rosianos, o sertanejo telúrico e cósmico, a se criar.

Voltando então à "Existenz", para Arendt, a refutação kantiana da prova ontológica da existência de Deus destruiu a crença racional em Deus. Não se pode mais demonstrar Deus por meio da razão. Assim, ele subtraiu do homem sua segurança em ser. $\mathrm{O}$ eu não sendo mais objeto do pensamento é um eu autônomo e justamente à autonomia do homem Kant chamava dignidade do homem. Para Arendt não é uma simples coincidência que a elucidação filosófica da era do homem coincida com a revolução francesa. Para ela, Kant é o filósofo da revolução francesa. A libertação e a autonomia conquistadas exclusivamente pela razão! O Ser não é mais dado, mas a realidade continua sendo. Ao conquistar sua liberdade o Homem perdeu sua realidade, por isso se 
encontra desabrigado. A cientista política observa que os conceitos de liberdade e dignidade humanas, princípio regulativo de toda ação política, foram abandonados, após Kant. O único problema da liberdade e autonomia kantianas é que elas são meramente racionais.

É digna de nota a tentativa de Marx de não interpretar o mundo, mas mudálo. Tanto o ser como o mundo deixam de ser dados e passam a ser produtos do homem. Por isso é materialista. Sua teoria revolucionária consiste na crença de que a essência pode mudar a existência e reciprocamente essa existência mudada mudaria a essência. Karl Löwith observa, sobre Karl Marx, que em "o Capital" a história é absorvida num processo econômico que caminha para uma revolução mundial final e uma renovação mundial (LÖWITH, 1977, pg. 43). A matriz do novo homem seria o proletário que tinha se afastado de si próprio, uma vez que se vende em troca de salário a um capitalista, detentor dos meios de produção. Assim, o proletário é o povo escolhido pelo materialismo histórico (LÖWITH, 1977, pg. 46-47). Talvez por isso Löwith chame o credo comunista de pseudomorfose do messianismo judaico-cristão. Porque no comunismo o proletário quer a glória, mas não o sofrimento, quer triunfar através da felicidade terrestre (LÖWITH, 1977, pg. 54).

A partir daí Arendt passa a definir a "Existenz" por meio do pensamento de três filósofos. Primeiramente, Kierkegaard opôs ao sistema hegeliano, de explicar "o todo", a pessoa única, o homem individual. Desse modo, a "Existenz" seria o caráter puramente factual de seu existir em toda a sua contingência. Essa "Existenz", que consiste que o que sou continuamente e não momentaneamente não pode ser apreendido pela razão, é a única coisa de que o homem pode estar inquestionavelmente seguro. Ser continuamente e não momentaneamente é um dos processos caros à literatura poética pelo menos desde as metamorfoses de Ovídio. Na verdade todo personagem poético se notabiliza por seu poder de mutação. Essa prática liga a literatura ao conceito de physis como brotação incessante de tudo. Na natureza tudo é recriação. Na Literatura um mundo novo emerge incessantemente a partir da tradição clássica. As folhas de uma árvore (material já existente) são naturalmente transformadas em adubo. Assim é o processo orgânico com tudo, nós mesmos viramos o adubo que alimenta a terra onde brotará o alimento que sustentará nossos filhos e netos. Nos alimentamos de nossos antepassados. Querendo ou não, somos antropofágicos! Tudo brota incessantemente inclusive o novo, daí vem o caráter originário de toda a poesia expressa na palavra poiésis. De qualquer modo, em Kierkegaard, as questões essenciais da filosofia passam a ser verdades subjetivas e não mais objetivas. No paradoxo o indivíduo pode apreender $\mathrm{o}$ universal e torná-lo conteúdo da sua "Existenz", mas é apenas no momento que ela está garantida. Uma contribuição importante que tanto Marx quanto Kierkegaard deram à filosofia foi o fato de desacreditarem da possibilidade de um conhecimento puramente contemplativo. Já Kierkegaard e Heidegger interpretaram a morte como "objeção" peculiar ao ser do homem, ela é a garantia do principium individuationis, e a contingência é a garantia da realidade como apenas dada, e a culpa seria categoria de toda a atividade humana. Esta subjetividade agonizante nos remete, no cenário da literatura brasileira, à poética de Clarice Lispector.

Heidegger quis desfazer a destruição iniciada por Kant do antigo conceito de ser. Para ele o ser é a temporalidade e por ser condicionado pela morte o ser é o nada. Assim, o livre-domínio do homem talvez fosse o nada, pois o homem não é um criador 
de mundo. Ora, eu perguntaria a Heidegger, o que é que os poetas fazem senão criar mundos? Outra coisa, todo o mundo da cultura é criado por quem senão pelos homens e mulheres? É claro que o mundo não é integralmente criado pelos homens e tem suas contingências próprias, mas boa parte dele é construído pelos homens. O homem tem a capacidade já demonstrada de criar mundos. De qualquer forma, Heidegger afirma que o homem é o ser onde essência e existência são idênticas. Para a metafísica tradicional a essência e a existência só coincidiam em Deus. Assim o homem seria um novo Deus, seria o "Senhor do Ser". Heidegger chama de "Existenz", ou Dasein, o ser do Homem e a apreensão dela seria o próprio ato de filosofar. Para ele, o que está em questão é o manter-se no mundo. Então, o ser no mundo é desabrigo e medo. A realidade humana seria um mero decair a partir de si mesma, uma vez que só na morte é que o homem teria a certeza de ser ele próprio. Seria uma espécie de catábase sem retorno, uma prisão nos infernos cada vez mais fundos. Para Arendt, em Heidegger o homem aparece apenas como um conglomerado de modos de ser, e o eu absolutamente isolado é desprovido de sentido; sendo a característica mais essencial desse Ser, ser do mais absoluto egoísmo.

Arendt considera que Jaspers inaugura a nova escola porque tira a "Existenz" do período do egoísmo. Ele busca filosofar a partir das situações-limite. Para Wolfgang Iser toda a ficção é uma transgressão de limites, sendo regida pelos três atos de fingir: a seleção, que faz escolhas arbitrárias no campo de sua referencialidade; a combinação que retira a palavra de sua referencialidade e a dá uma nova, transformando o signo vernáculo em símbolo poético; e o que a caracteriza propriamente como ficção que é o autodesnudamento de sua ficcionalidade. É sempre a própria obra poética que inaugura a sua constelação crítica, porque ela é a primeira a fazer sua própria crítica. A origem conhecida da crítica literária consiste nas parábases aristofânicas em que um corifeu se desligava da cena das ações dos personagens e fazia a crítica da peça dirigindo-se diretamente ao público, situação tão cara aos nossos Machado de Assis e Guimarães Rosa. Voltando a Jaspers, para ele a "Existenz" não é nenhuma forma de ser, mas uma forma de liberdade. Sendo assim a "Existenz" é o homem como possibilidade de sua espontaneidade, o homem volta-se contra seu ser como mero resultado. Pois essa definição casa muito bem com a definição que Bakthin faz do personagem poético ao dividir a literatura universal em duas correntes, a monológica e a polifônica. O personagem poético é aquele se rebela contra as definições objetificantes que o narrador ou outros personagens tentam lhe impor. O texto polifônico é tecido por meio de mundividências autônomas e livres que se entrelaçam em absoluto pé de igualdade na grande narrativa. O princípio filosófico da polifonia consiste em que a verdade em si é incognoscível, então o único modo de se aproximar de uma verdade é conhecendo o emaranhado de narrativas que existem acerca daquela verdade. Quanto mais narrativas conheço acerca de uma verdade mais me aproximo dela. Para Jaspers o ser é incognoscível e deve ser experimentado como algo que nos envolve. O Quê do Ser como dado torna-se o pano de fundo contra o qual a liberdade humana emerge, e o homem realiza sua liberdade no mundo por intermédio da atividade. Por isso a comunicação é fundamental, para respeitarmos, conhecermos, os limites das liberdades dos outros para que não as ultrapassemos, assim como para que os outros conheçam igualmente os limites da nossa própria liberdade para que ela não seja invadida. Assim, o ser é tal que essa realidade humana é possível. De qualquer forma, o Ser parte do mundo ilusório do pensamento para os limites da realidade, que não é um objeto do pensamento. Fica 
claro assim o grau de ficcionalidade que existe em toda a construção de visão do mundo. Mas o homem é mais real e mais livre do que seu pensamento. É o pensamento que está submetido ao homem e não o homem a ele. Portanto, transcender seria conduzir-se em pensamento aos limites do pensável. A transcendência só se dá quando o pensamento fracassa, pois ultrapassar o pensamento é uma experiência de fracasso do pensamento que tem que ser ultrapassado para que se atinja alguma compreensão. Esse fracasso é um sinal da limitação da "Existenz" humana, limitação que é determinada pela filosofia. Assim, o fracasso é a condição da "Existenz". Portanto, a tarefa da filosofia é libertar o homem do mundo ilusório do objeto puro do pensamento. A natureza do homem então é ser mais do que ele próprio e querer ser mais do que ele próprio. Se em Heidegger o outro destrói a "Existenz", em Jaspers ela só pode se desenvolver no estar junto.

A questão do ser do homem levantada pela filosofia da "Existenz" parece suscitar a questão do governo do ser. O Ser deve ser governado autoritariamente ou em liberdade; deve ser submetido a outro "ser superior" ou governar a si mesmo em solidariedade com seus pares? As questões relativas ao autoritarismo, por que passou com o nazismo, leva Hanna Arendt a pensar o papel da compreensão na luta contra o totalitarismo. Ela se volta contra todo o tipo de totalitarismo, seja ele nazista, fascista ou bolchevique. Vale lembrar que Autran Dourado imputa à obrigatoriedade da confecção somente da literatura denominada como realismo socialista a causa da paralisia da grande literatura russa que se praticava até então. A Literatura poética, como a compreensão, só brota no terreno fértil da liberdade. Para Arendt, a compreensão é a atividade interminável, por meio da qual, em constante mudança e variação, aprendemos a lidar com a realidade, reconciliando-nos com ela. A compreensão é a maneira especificamente humana de estar vivo. Na literatura, a purificação da catarse tem muito a ver com a reconciliação do ser com o mundo e consigo mesmo, isso está de forma irônica em Machado de Assis, trágica em Clarice Lispector e caleidoscópica em Guimarães Rosa. Para Arendt antes mesmo de compreender o totalitarismo devemos combatê-lo. Esse combate nunca pode se dar numa forma de doutrinação, pois a doutrinação é uma deturpação da compreensão. Para ela, a doutrinação só faz promover a luta totalitária contra a compreensão. O totalitarismo não é exclusividade de governos totalitários, todas as sociedades livres guardam traços totalitários. Como vimos, a sociedade livre do Rio de Janeiro vive sob um regime com os traços totalitários do choque de ordem. O totalitarismo é a ânsia do poder, a vontade de dominar, o terror, a chamada estrutura estatal monolítica e a ditadura de um partido só. A condição central para a tirania é a perda da capacidade de ação política, perda de busca de significado, da necessidade de compreender. A transformação totalitária deturpa a "ideia", transformando-a em premissa, no sentido lógico. Como já foi observado, a lógica rigorosa é a característica fundamental do pensamento totalitário.

Se Arendt se opõe ao primado da lógica, ela faz o necessário elogio do senso comum. A compreensão tem limites claros. Ela não pode causar efeitos imediatos na realidade. Compreensão e conhecimento não são a mesma coisa, mas interligam-se. O pensamento seria o "dois-em-um" - da consciência socrática dividida - do diálogo sem som; para Platão é o diálogo sem som de mim comigo mesmo. O pensamento realiza a diferença no interior da identidade. Emmanuel Carneiro Leão (LEÃO, 1976) interpreta que o fragmento de Heráclito que diz que "Dionísio Zagreus e o Hades é o mesmo" (HERÁCLITO, 1980), introduz justamente a diferença representada por Dionísio na mesmice da identidade do Hades. Para enquadrar Dioniso na diferença, basta 
lembrar que nAs Bacantes (EURÍPEDES, 1998) ele aparece como homem, Deus e animal. A compreensão baseia-se no conhecimento, que não se pode dar sem que haja uma compreensão preliminar. É preciso conhecer algo primeiro, por meio da compreensão preliminar, para depois compreendê-lo. Desse modo, a compreensão precede e sucede o conhecimento, envolve-o. A compreensão preliminar aponta o totalitarismo como tirania: ao lutarmos contra a dominação, lutamos pela liberdade. Não é preciso esperar pela compreensão para lutarmos contra o totalitarismo, a compreensão preliminar já basta. A linguagem popular ao expressar uma compreensão preliminar inicia assim o processo da verdadeira compreensão. Talvez seja por isso que Rosa tenha escolhido criar uma linguagem oral, popular, sertaneja; para gerar um verdadeiro processo de compreensão pela palavra poética. Arendt observa que o uso popular da palavra totalitarismo com o propósito de denunciar um mal político supremo começou após a segunda guerra, antes disso a palavra usada para determinar governos autoritários era a palavra imperialismo. Ela observa que, por se basear na tradição, é provável que a autoridade tenha uma origem política romana. Para ela, só mesmo a queda do imperialismo, aceita depois da falência do império britânico e a entrada da Índia na comunidade britânica, justifica que o totalitarismo tenha tomado o lugar do imperialismo. A compreensão preliminar logo situa o novo em meio ao antigo. A linguagem popular reconhece o novo pela aceitação de uma palavra nova. Segundo o próprio Guimarães Rosa, "Somente renovando a língua é que se pode renovar o mundo." Ele afirma a Günter Lorenz que "minha língua... é a arma com a qual defendo a dignidade do homem." (LORENZ, 1983, p. 87-88) Assim, o totalitarismo só se tornou um tópico de estudo corrente quando a compreensão preliminar reconheceu-o como questão central e o mais significativo perigo de sua época. Dessa forma vai se fazendo o elogio do senso comum, que pressupõe um mundo comum no qual todos cabemos e onde podemos viver juntos por possuirmos afinidades, em contraposição à lógica, que só pode reivindicar sua confiabilidade de forma totalmente independente do mundo e da existência de outras pessoas. Essa questão me remete à narrativa rosiana denominada "Conversa de Bois" na qual um boi, o boi Brilhante, conta a estória de outro boi chamado Rodapião. $\mathrm{O}$ boi Rodapião não concordava com o jeito de os outros bois se comportarem, espontaneamente, bovinamente. O boi Rodapião queria fazer como os homens, queria agir racionalmente. E assim faz o boi Rodapião que o tempo todo só se dá mal. Até que ele tenta cortar o caminho por meio de um atalho que passava por cima de um monte. Por só estar preocupado com o raciocínio e não com o corpo, o boi Rodapião não percebe que a grama está orvalhada e escorrega na lama, caindo de cima do monte e morre. Foi isso que a humanidade, a alienação de sua condição bovina, a racionalidade, do boi Rodapião custou a ele, uma morte horrível, dolorosa e solitária. Por isso Ronaldes define "Conversa de Bois" como uma ironia ao sistema patronal, uma vez que os animais se tratam como iguais e os homens se dominam uns aos outros (SOUZA, 2008, p. 107). Para Arendt, Paul Valéry foi o primeiro a detectar a bancarrota do senso comum no mundo moderno. Perdemos nossos instrumentos para compreender. A nossa busca por significado é ao mesmo tempo estimulada e frustrada por nossa inabilidade em produzir significado.

Para Arendt foi a mudança radical por que passou o mundo na Revolução Industrial que causou a falência dos costumes. Segundo ela, em poucas décadas essa revolução alterou mais o globo terrestre do que os 3 mil anos anteriores de história registrada. A falência dos costumes consiste em que nunca antes na história das civilizações as 
pessoas foram suficientemente ingênuas para adquirir hábitos de compra, segundo a máxima "o autoelogio é a melhor recomendação", pressuposto de toda a propaganda. Franklin de Oliveira observa que "o fascismo é impensável dissociado do império do dinheiro." (OLIVEIRA, 1983, p. 184). Ao tratar de história, como refuta a lógica, Arendt refuta também o tratamento causal dado por determinados historiadores à história. Para ela, a causalidade é uma categoria totalmente estranha e falseadora no que diz respeito às ciências históricas. A categoria de causalidade também é totalmente estranha e falseadora da literatura poética, que entrelaça imagens ciclicamente. Só a literatura monológica trabalha com causalidade, toda a sua trama se reduz a simples antecedentes e consequentes para tentar "prender" a atenção do leitor por meio da curiosidade quanto ao que vai acontecer. Para Arendt, as causalidades, generalizações e categorizações extinguem a luz natural que a história oferece, destroem a verdadeira história com seu significado eterno. Como a literatura, a história sem os eventos torna-se a monotonia morta da mesmice desdobrada no tempo. A história é uma estória que tem muitos começos, mas nenhum fim (que seria o desaparecimento do homem sobre a face da terra). A importância que o conceito de começo e origem tem nas questões políticas advém de que toda a ação política é sempre essencialmente o começo de algo novo, como tal ela é a própria essência da liberdade humana. Em latim, agere é pôr em movimento, desencadear um processo. Esse é um dos motivos pelos quais toda obra nova é a recriação das obras clássicas: tem-se que voltar à origem para fazer o novo. Começar algo novo é um tema caro à filosofia e à ciência política. Em Santo Agostinho o homem não só tem a capacidade de começar como ele mesmo é esse começo. Para Maquiavel o ato de fundação em si requer e justifica o ato da violência. Já vimos como esta questão maquiavélica de que os fins justificam os meios causou a cisão do comunismo em marxista e libertário. Mas, como já vimos, o pensamento libertário não exclui totalmente a violência, como na teoria de Malatesta, que crê no uso da violência como autodefesa da violência a qual a classe opressora nos submete. Simples enganos de leitura a esse respeito levaram alguns grupos, que se denominaram equivocadamente de anarquistas, a cometerem atos violentos, o que levou a anarquia a ser, injustamente, acusada de pregar a desordem e promover a violência. Mas Malatesta tem toda a razão em tirar a violência do âmbito dos meios e colocá-la no da autodefesa.

Por fim, Arendt atualiza a prece de Salomão que pede a Deus um coração compreensivo, estabelecendo que o coração compreensivo é a faculdade da imaginação. Ora, se compreender está intimamente ligado ao poder de imaginação então a literatura é o campo privilegiado do conhecimento. Para ela, é importante distinguir a imaginação da fantasia, pois mobilizar seu poder não significa tornar irracional a compreensão dos assuntos humanos. Só a imaginação nos permite ver as coisas em suas perspectivas próprias, assim como na literatura polifônica. A imaginação nos permite penetrar nos pensamentos e sentimentos, por exemplo, daqueles bois de Rosa, o Brilhante, que conta a história do outro boi, o Rodapião. Sem a imaginação nunca penetraríamos nessas perspectivas originais e originárias. 


\section{Referências Bibliográficas}

ALBERGARIA, Consuelo. Bruxo da Linguagem no Grande Sertão. Rio de Janeiro: Tempo Brasileiro, 1977.

ARENDT, Hannah. A Dignidade da Política: Ensaios e Conferências. Rio de Janeiro: Relume-Dumará, 1993.

ARROYO, Leonardo. A Cultura Popular em Grande Sertão: veredas. Rio de Janeiro: José Olympio Editora; [Brasília]: INL, 1984.

BARBOSA, Alaor. A Epopeia Brasileira ou: para ler Guimarães Rosa. Goiânia: IMERY publicações LTDA, 1981.

BASTOS, Dau. Guimarães Rosa: sombra ou sol da posteridade? In: Secchin et al. (Org.). Veredas no Sertão rosiano. Rio de Janeiro: 7Letras, Setembro de 2007.

BUONFIGLIO, Leda Velloso. O 'direito à cidade' apropriado: da utopia dos sem-teto ao modelo de gestão do Estado. Florianópolis: Anais do II Seminário Nacional Movimentos Sociais, Participação e Democracia, 25 a 27 de Abril de 2007. URL: < http:// www.sociologia.ufsc.br/npms/leda_buonfiglio.pdf $>$.

CASTRO, Iná Elias de. Espaços Públicos: entre a publicidade e a política. In: Alceu: Revista de Comunicação, Cultura e Política. v. 4, n. 8, jan./jun. 2004-. Rio de Janeiro: PUC, Dep. de Comunicação Social.

COELHO, Nelly Novaes; VERSIANI, Ivana. Guimarães Rosa (Dois Estudos). São Paulo: Quíron; [Brasília]: INL, 1975.

COVIZZI, Lenira Marques; NASCIMENTO, Edna Maria F. S. Lendo João Guimarães Rosa, Homem Plural Escritor Singular. São Paulo: Editora Atual, 1985.

DOURADO, Autran. Uma Poética do Romance: Matéria de Carpintaria. São Paulo: Perspectiva, 1973.

EURÍPEDES. As Bacantes. Trad. e apresentação de Mário da Gama Kury. Rio de Janeiro: Jorge Zahar, 1998.

GALVÃO, Walnice Nogueira. As Formas do Falso. São Paulo: Perspectiva, 1972.

GRANDI, Matheus da Silveira; TEIXEIRA, Eduardo Tomazine. O agir comunicativo e sua espacialidade: Reflexões a partir do exemplo da ocupação Chiquinha Gonzaga, no Centro do Rio de Janeiro. s/d. URL: < http://www.geografia.ufrj.br/nuped/ textos/agir-comunicativo_e_espacialidade.pdf $>$

HERÁCLITO. Fragmentos. Tradução, introdução e notas de Emmanuel Carneiro Leão. Rio de Janeiro: Tempo Brasileiro, 1980.

LAGES, Susana Kampff. João Guimarães Rosa e a Saudade. São Paulo: Ateliê Editorial, 1998.

LEÃO, Emmanuel Carneiro. O pensamento originário. Rio de Janeiro: Revista Tempo Brasileiro, n. 47, p. 3-13, Outubro-Dezembro de 1976.

LEITE, Dante Moreira. Grande Sertão: veredas. In: O Amor Romântico e Outros Temas. São Paulo: Editora da USP, 1979.

LORENZ, Günter. Diálogo com Guimarães Rosa. Rio de Janeiro: Civilização Brasileira; [Brasília]: INL, 1983. (Coleção Fortuna Crítica, v.6)

LÖWITH, Karl. O Sentido da História. Rio de Janeiro: Edições 70, 1977.

LUCCHESI, Marco. Monumental Afresco da História. In: A Ciência Nova. Rio 
de Janeiro - São Paulo: Editora Record, 1999.

MARX, Karl. A Guerra Civil na França. In: A Revolução antes da Revolução. São Paulo: Expressão Popular, 2008.

MELO, Antonio M. Barbosa de. Prefácio da Ciência Nova. In: Ciência Nova (Giambattista Vico), Lisboa: Fundação Calouste Gulbenkian, 2005.

OLIVEIRA, Nathalia Cristina. Os movimentos dos sem-teto da cidade de São Paulo frente aos governos neoliberais (1995-2002). Campinas: IV Colóquio Marx e Engels - Cemarx/Unicamp, 2002. URL: < http://www.unicamp.br/cemarx/ANAIS\%20IV\% 20COLOQUIO/paineis/GT3/gt3p13.pdf > .

OLIVEIRA, Franklin de. Revolução Roseana. Rio de Janeiro: Civilização Brasileira; [Brasília]: INL, 1983. (Coleção Fortuna Crítica, v.6).

PACHECO, José. Escola da Ponte Formação e Transformação da Educação. Petrópolis: Editora Vozes, 2008.

PORTELLA, Eduardo. A Estória contra a História. Rio de Janeiro: Civilização Brasileira; [Brasília]: INL, 1983. (Coleção Fortuna Crítica, v.6)

RODRIGUES, Glauco Bruce; SOUZA, Marcelo Lopes de. MTST e hip hop: os "novíssimos ativismos urbanos". In: Planejamento Urbano e Ativismos Sociais. São Paulo: UNESP, 2004.

RÓNAI, Paulo. Os Vastos Espaços. In: Primeiras Estórias. Rio de Janeiro: Nova Fronteira, 2005.

ROSA, João Guimarães. Grande Sertão: veredas. Rio de Janeiro: Editora Nova Fronteira, 2006.

. Sagarana. Rio de Janeiro: José Olympio, 2001.

ROUSSEAU, Jean-Jaques. O CONTRATO SOCIAL e outros escritos. São Paulo: Editora Cultrix, 1980.

SOUZA, Ronaldes de Melo e. A Saga rosiana do Sertão. Rio de Janeiro: Eduerj: 2008.

SPERBER, Suzi Frankl. À Busca da Liberdade e as Regras do Direito em Grande Sertão: veredas. Scripta, Belo Horizonte, v. 5, n. 10, 1. semestre de 2002. p. 334-342.

VIGGIANO, Alan. O Itinerário de Riobaldo. Porto Alegre: Editora Mercado Aberto, 1993.

WARD, Teresinha Souto. O Discurso Oral em Grande Sertão: veredas. São Paulo: Duas Cidades; [Brasília]: INL, Fundação Nacional Pró-Memória, 1984. 